\title{
UV-Based Technologies for SARS-CoV2 Inactivation: Status and Perspectives
}

\author{
Nicola Trivellin ${ }^{1,2, *}$, Francesco Piva ${ }^{2}$, Davide Fiorimonte ${ }^{1}$, Matteo Buffolo ${ }^{2}$, Carlo De Santi ${ }^{2}$, \\ Viviana Teresa Orlandi ${ }^{3}{ }^{-}$, Fabrizio Dughiero ${ }^{1}$, Gaudenzio Meneghesso ${ }^{2}{ }^{\circledR}$, Enrico Zanoni ${ }^{2}$ \\ and Matteo Meneghini ${ }^{2}$ (I)
}

check for

updates

Citation: Trivellin, N.; Piva, F.; Fiorimonte, D.; Buffolo, M.; De Santi, C.; Orlandi, V.T.; Dughiero, F.; Meneghesso, G.; Zanoni, E.;

Meneghini, M. UV-Based

Technologies for SARS-CoV2 Inactivation: Status and Perspectives. Electronics 2021, 10, 1703. https:// doi.org/10.3390/electronics10141703

Academic Editors: Mengmeng Li, Brett D. Nener and Mattias Hammar

Received: 14 June 2021

Accepted: 13 July 2021

Published: 16 July 2021

Publisher's Note: MDPI stays neutral with regard to jurisdictional claims in published maps and institutional affiliations.

Copyright: (c) 2021 by the authors. Licensee MDPI, Basel, Switzerland. This article is an open access article distributed under the terms and conditions of the Creative Commons Attribution (CC BY) license (https:// creativecommons.org/licenses/by/ $4.0 /)$.
1 Department of Industrial Engineering, University of Padova, Via Gradenigo 6A, 35131 Padova, Italy; davide.fiorimonte@unipd.it (D.F.); fabrizio.dughiero@unipd.it (F.D.)

2 Department of Information Engineering, University of Padova, Via Gradenigo 6B, 35131 Padova, Italy; francesco.piva@unipd.it (F.P.); matteo.buffolo.1@unipd.it (M.B.); carlo.desanti@dei.unipd.it (C.D.S.); gaudenzio.meneghesso@unipd.it (G.M.); enrico.zanoni@unipd.it (E.Z.); matteo.meneghini@unipd.it (M.M.)

3 Department of Biotechnology and Life Sciences, University of Insubria, Via J.H. Dunant 3, 21100 Varese, Italy; viviana.orlandi@uninsubria.it

* Correspondence: nicola.trivellin@unipd.it

\begin{abstract}
Severe acute respiratory syndrome coronavirus 2 (SARS-CoV-2) is the etiologic agent of COVID-19, which has affected the international healthcare systems since the beginning of 2020 . Among sanitizing approaches, UV irradiation is a well-known technology often used in different environments to reduce the microbial contamination and the viral transmission. In particular, several works have demonstrated that UVC radiation is able to inactivate SARS-CoV-2 compromising its viral genome and virion integrity. With this work we review and analyze the current status of the pandemic and the state of the art of the UV technology. With traditional UVC discharge lamps having a serious environmental issue, due to their working principle based on mercury, a primary focus is shifted on the aluminum gallium nitride based deep-ultraviolet light emitting diodes. These devices are exploited for compact and environmentally friendly disinfection systems, but efficiency and reliability still play a limiting role into their mass market adoption and system efficacy. In this work we then analyze the latest reports on the effects of dose and wavelength on viral inactivation, thus providing two key pillars for the development of UVC based disinfection systems: the status of the technology and a quantitative evaluation of the dose required to achieve an effective coronavirus inactivation.
\end{abstract}

Keywords: ultraviolet; LED; SARS; covid; virus; antiviral

\section{Introduction}

SARS-CoV-2 has been first identified as the etiological agent of pneumonia in patients from Wuhan, China [1]. The related infection (COVID-19) has been declared a pandemic by the WHO (World Health Organization) on 11 March 2020. Nowadays, upon prophylaxis through vaccination and patient treatment with optimized therapeutic agents, the viral spread, infection and death rates are decreasing. However, until now more than 3.5 million deaths worldwide have been estimated [2] and the reported cases are still numerous in many countries (see Figure 1). At the same time, however, different mutant strains are emerging and have been studied, indicating a change in transmissibility, clinical symptomatology and severity with respect to the "wild-type" virus sequenced after the diffusion in Wuhan, China. At the moment researchers have isolated 4 variants of concern (VOCs): B.1.1.7 (Alpha, UK, September 2020), B.1.351/B.1.351.2/B.1.351.3 (Beta, South Africa, May 2020), P.1/P.1.1/P.1.2 (Gamma, Brazil, November 2020), and B.1.617/AY.1/AY.2 (Delta, India, October 2020). To the 4 VOCs, 6 different variants of interest (VOIs) are currently under investigation. These variants might contribute in a faster transmission of the virus [3], mutant strains of SARS-CoV-2 are also found to be mostly responsible for COVID-19 reinfection [4]. Although several actions can be put in place, two major solution will allow to 
deal with the pandemic, first by reducing the morbidity and the symptoms, and secondly simply by reducing the risk of being infected by the virus. If the first objective can be met for example by the use of vaccines, the second can be achieved through interruption of the transmission lines. Normal speaking [5] or coughing [6] can generate droplets and aerosol containing the virus, thus leading the respiratory virus transmission. While personal protection devices such as face masks are effective toward the spread of droplets, for example, a fluid-resistant (Type-IIR) surgical facemask is expected to reduce the droplet dispersion by at least $80 \%$ [4-6], contamination of surfaces [7], water and air must also be prevented to minimize the spread of the virus. Thus, it is important, in antimicrobial field, to distinguish sterilization from sanitization. The aim of sterilization is to destroy or eliminate all forms of microorganisms (bacteria, archaea, fungi, parasites) or viruses present on the surface of an object; the goal of sanitization is to eliminate most pathogenic microorganisms, except bacterial spores, on inert surfaces. The term disinfection is used for treatment of living tissues, such as human and animal skin. If the attention is focused on viral target, virus inactivation is defined as "a loss of viral titer with time due to disruption of coat proteins and degradation of nucleic acid" [7], thus rendering the virion not able to infect host cells and compromising viral replication.

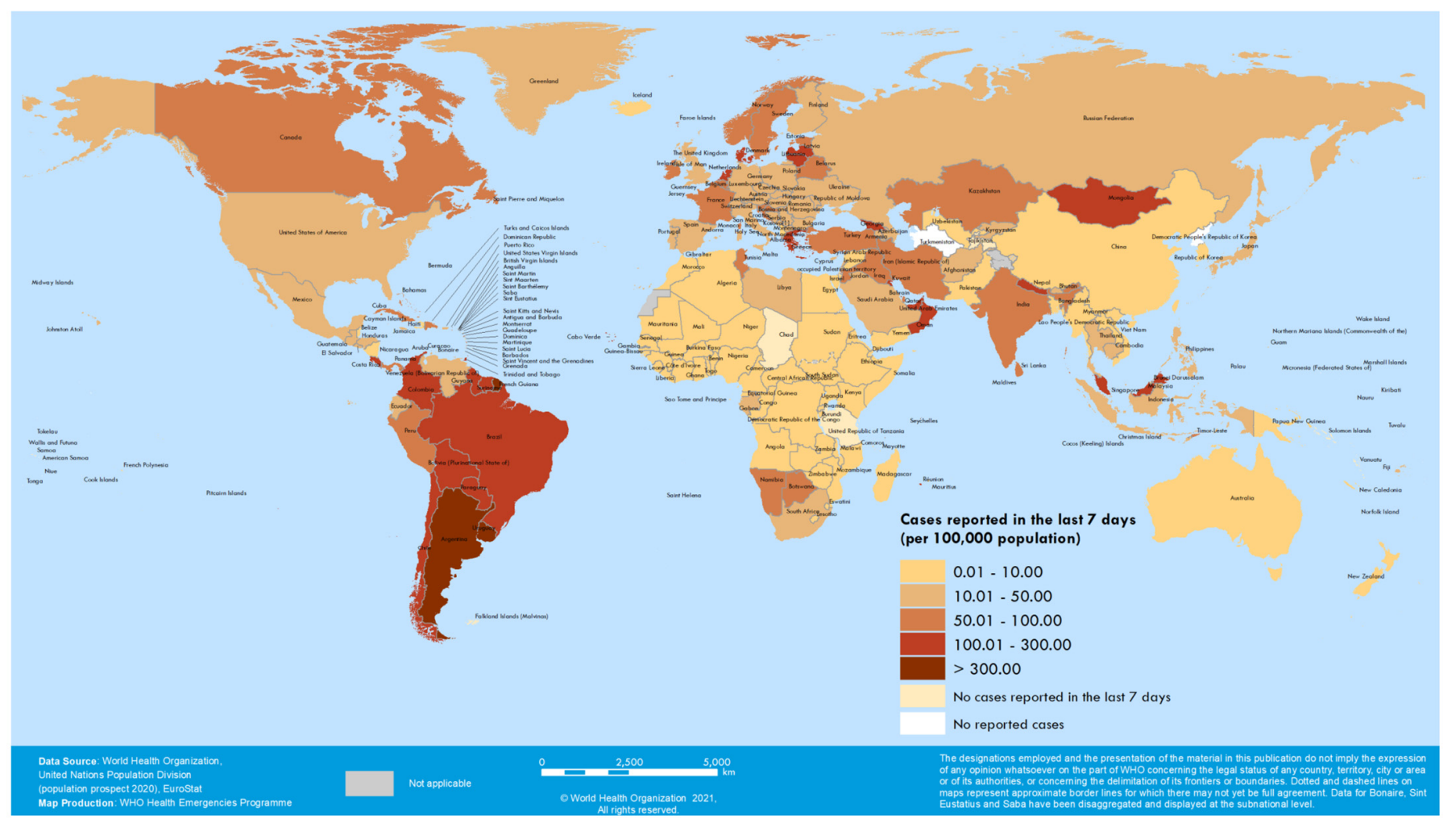

Figure 1. Cases reported in the period 24-30 May 2021, courtesy of WHO [2] Licence: CC BY-NC-SA 3.0 IGO.

The inactivation of viral agents can be achieved by means of different strategies, here we report the two main approaches: (a) chemical action or (b) physical action [7].

\subsection{Control of Microorganisms and Viruses by Chemical and Physical Treatments}

Biocidal agents used commonly for chemical sanitization are based on several active compounds like Alcohols, Phenols, Halogen derivatives and Quaternary ammonium salts. Among Alcohols, Ethanol and 2-Propanol are considered an effective surgical disinfectant [8]. Alcohols denature proteins in the cytoplasmic membrane and cell wall of Gram-positive and Gram-negative bacteria, and proteins from viral capsid and/or envelope. As used in the hand sanitizing gel compounds Ethanol has a higher bactericidal effect when mixed with water $(70-95 \%)$ because proteins are denatured more efficiently 
in aqueous solution [8,9]. Among halogens, Chlorine and chlorine compounds and, in particular hypochlorite are oxidant compounds able to oxidize proteins and enzymes. They are widely used in healthcare facilities due to the low cost, the broad spectrum of antimicrobial activity, and fast action [10]. However, they can cause eye and skin irritation, respiratory apparatus burns, and metal corrosion. Iodine based disinfectant act binding amino groups $\left(-\mathrm{NH}_{2}\right)$ of aminoacids and disrupting proteins. Povidone-iodine is the most widely used iodine-based disinfectant. By mixing polyvinylpyrrolidone with iodine it is possible to gradually release the iodine in aqueous solution, thus inducing an enduring sanitization action. Cationic Quaternary ammonium salts, such as benzalkonium chloride, are often used in nosocomial environment sanitization. These compounds are responsible for protein denaturation, enzyme inactivation and biological membrane disruption.

All of these chemical compounds are reported to be effective toward the inactivation of enveloped viruses [11] and are suggested for use in Sars-COV-2 inactivation [12]. In particular, Kampf reported that human coronaviruses such as Severe Acute Respiratory Syndrome (SARS-CoV and SARS-CoV-2) coronavirus, Middle East Respiratory Syndrome (MERS) coronavirus or endemic human coronaviruses $(\mathrm{HCoV})$ can be efficiently inactivated by $62-71 \%$ ethanol, $0.5 \%$ hydrogen peroxide or $0.1 \%$ sodium hypochlorite within $1 \mathrm{~min}$. Other biocidal agents such as $0.05-0.2 \%$ benzalkonium chloride or $0.02 \%$ chlorhexidine digluconate were less effective [13].

Chemical disinfectants, however, are also affected by several drawbacks, they are generally provided in the form of liquids and a drying action needs to be carried out after the treatment, they might be dangerous or event toxic for humans, the effective disinfection level of a target surface depends on the operator ability to correctly spread the liquid and is therefore prone to human errors.

It is well known that several chemical and physical parameters (i.e., temperature, oxygen tension, saline concentration, $\mathrm{pH}$, water availability, light) influence the growth of microorganisms. Thus, in antimicrobial field, the containment of microbial pathogens can be obtained changing few physical parameters. However, the same procedures are efficient against viral agents. For example, inside an autoclave the steam sterilizes inanimate objects thanks to the protein denaturation occurring under heat treatment $\left(121^{\circ} \mathrm{C}\right.$ for $30 \mathrm{~min}$ or $132{ }^{\circ} \mathrm{C}$ for $4 \mathrm{~min}$ ) [14]. Ozone gas, due to its strong oxidative power, has been reported to inactivate microorganisms and viruses on various surfaces $[14,15]$. It has also been demonstrated that Ozone can degrade the RNA genome of SARS Cov-2 on the surface of face masks [16] with important advantages with respect to chemical based processes: no structural damage on the filter layer of face masks, no functional deterioration on face masks, and not leftovers in the treated masks occur.

\subsection{UV Irradiation in Viral Inactivation}

Ultraviolet light refers to an electromagnetic radiation with a wavelength comprised between $100 \mathrm{~nm}$ and $400 \mathrm{~nm}$. According to standard ISO 21348:2007, ultraviolet radiation is subdivided into 4 categories: UVA (315-400 nm), UVB (315-280 nm), UVC (200-280 nm), Vacuum UV-UVV (100-200 nm). As the wavelength decreases the energy of every photon increases and the interaction with different organic and inorganic compounds changes: UVA radiation is known to cause tanning to skin and also long-lasting damages. UVB can be used to treat some skin disease like psoriasis. UVV radiation is absorbed by the atmosphere and therefore is not useful in an environmental condition. UVC is the most interesting for antimicrobial purposes, since it has been demonstrated to being the most effective toward the inactivation of both bacteria and viruses.

From a biological point of view, UVC affects nucleic acids composing genome of eukaryotic cells, prokaryotic microorganisms and viruses. Both DNA and RNA are modified by the absorption of high energy UVC photons. The UVC radiation acts mostly on two consecutive Thymine residues, causing the collapse of Hydrogen bonds between Thymine and Adenine, and forming a new Thymine-Thymine dimer, as shown in DNA representation (Figure 2) Furthermore, other photoproducts can arise: Cytosine-Cytosine dimer, 
Cytosine-Thymine dimer, Uracil-Uracil dimer, Uracil-Thymine dimer and Uracil-Cytosine dimer [17] In particular, for antiviral purposes, the compromising of viral genome prevents viral replication [18].
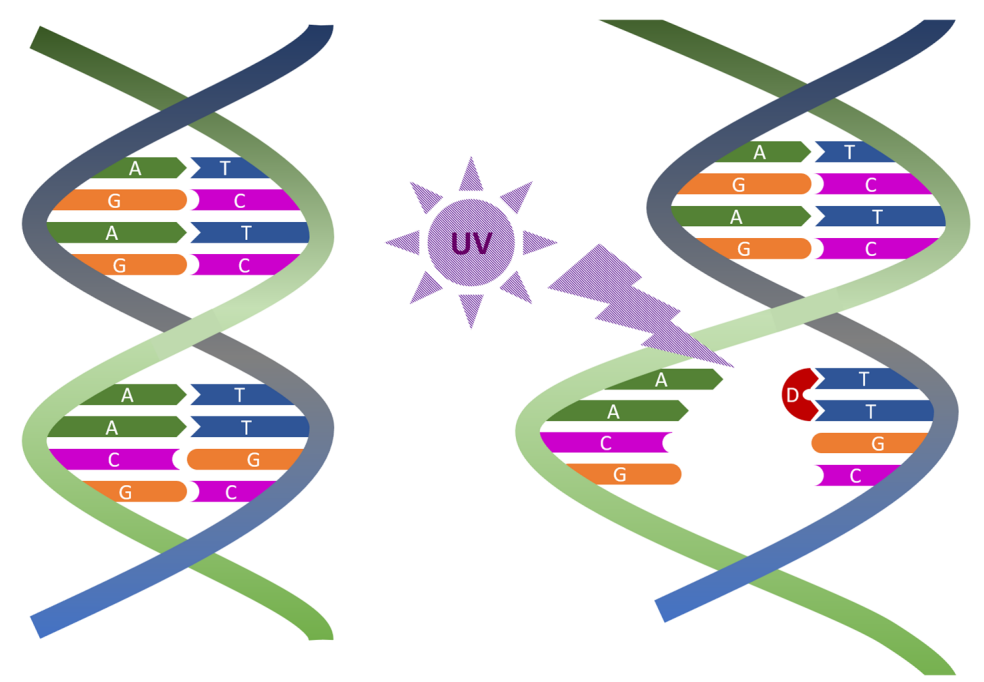

Figure 2. Sketch of the effects of UVC radiation on DNA sequence.

The amount of DNA damages which can be caused by UVC photons is related to the number of absorbed photons by the biological entities: it has been demonstrated that the UVC viral inactivation is wavelength and radiation-dose related dependent. In Figure 3, we report the relative inactivation rate of Human Coronavirus [19] and Bacillus subtilis spores, that represent the most difficult microbial target to kill [20]. It is interesting to notice that the inactivation rate of spores and virus depends on the wavelength. Furthermore, it has been demonstrated that the dose response can not only related to the absorbance spectrum of nucleic acids, but other components of the irradiated microbiological target should be considered.

Several papers indicated that UV radiation can be effective towards the inactivation of different pathogenic microorganisms and viruses, including, recently, SARS-CoV-2 [21-23] on surfaces; main results and technological issues are reported in the following.

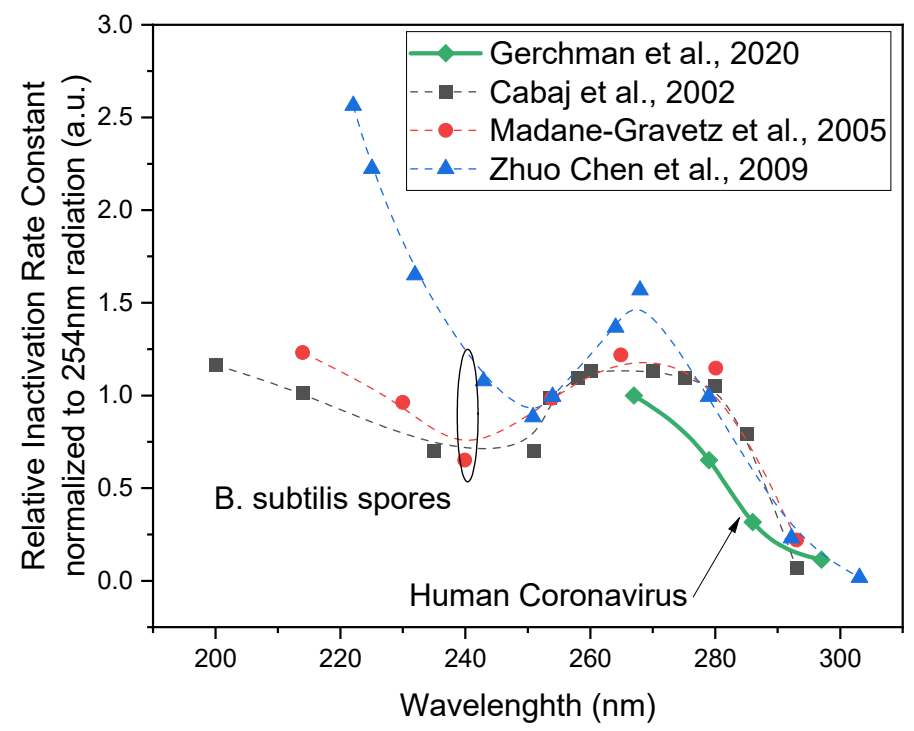

Figure 3. Relative inactivation rate of Bacillus subtilis spores and Human Coronavirus as a function of wavelength $[19,20,24,25]$. 


\subsection{UVC Sources}

UVC radiation can be emitted by the luminescence of an ionized gas excited by means of a potential difference. Discharge lamps are based on Mercury vapors and are subdivided in: low pressure mercury lamps, amalgam lamps, and medium pressure UV lamps. In Table 1 we summarize the typical characteristics of UVC discharge lamps.

Table 1. Types of UVC discharge lamp and main characteristics.

\begin{tabular}{ccccc}
\hline Type of Lamp & Wavelength & UVC Efficiency & Power Density & Useful Life \\
\hline Low pressure & $254 \mathrm{~nm}$ & $35 \%$ & $0.8-1.3 \mathrm{~W} / \mathrm{cm}$ & $12,000 \mathrm{~h}$ \\
Amalgam & $254 \mathrm{~nm}$ & $33 \%$ & $1-6 \mathrm{~W} / \mathrm{cm}$ & $>12,000 \mathrm{~h}$ \\
Medium pressure & Broad & $15 \%$ & $80-300 \mathrm{~W} / \mathrm{cm}$ & $1000-5000 \mathrm{~h}$ \\
\hline
\end{tabular}

UVC discharge lamps are able to emit a high radiation intensity with good efficiency, however they suffer from important drawbacks: mercury is highly pollutant [26], their lifetime is quite limited particularly for a continuous usage, they require a certain turn on time (generally in the order of few seconds to some minutes) before reaching the rated optical output power, and their size do not allow an easy integration into small size systems or chambers.

An alternative to discharge lamp is given by Light Emitting Diodes (LEDs) with emission in the UVC region. Deep ultraviolet LEDs are based on aluminum gallium nitride $(\mathrm{AlGaN})$ material and have been available for approximately two decades [27]. Nevertheless, their limited performance [28], reliability [29] and high cost per watt played a major role in limiting their market diffusion. Recently, the efficiency of these devices has risen up to levels of $1-3 \%$, while a sensible reduction of cost (in the order of $€ 300-400$ per optical watt as proposed by main on-line electronic components distributors at the time of writing) made them suitable for different commercial applications. UVC LEDs are still less efficient than low pressure mercury lamp, but their compactness, low voltage operation and instant turn-on compensate for these deficiencies. Reliability of UV LEDs is fundamental to guarantee a stable antiviral effect and a long lifetime for the disinfection systems. Degradation of the optical and electrical parameters of UV LEDs is currently under investigation by several research groups and manufacturers, the main results and state of the art outcomes are reported in the next section.

\section{Challenges of UV LEDs}

As previously described, UV radiation consists in the wavelength range below the visible light and is subdivided into UVA, UVB, UVC and UVV, each range presents different applications (examples are reported in Figure 4) and different problematics in the realization of UV devices; at the time being, these applications brought greater developments for the LEDs at the wavelengths with a bigger interest, but a development is expected in the next years for the whole UV range.

In the first years of 2000, a great interest was around the UVA range, where the key applications are: the UV curing and drying of inks, paints, coatings, resins, polymers and adhesives (365-400 $\mathrm{nm}$ ) [31-33] where the light initiate photochemical reactions, the development of security systems for the recognition of identity cards and banknotes through a fluorescent pigment $(350 \mathrm{~nm})$ [34], and spectroscopy for medical application $(320-400 \mathrm{~nm})$ [35]. All these implementations brought the research to the realization of UVA LEDs with EQEs exceeding 50\% (Figure 5), lower levels in respect to visible LEDs, but still acceptable. 


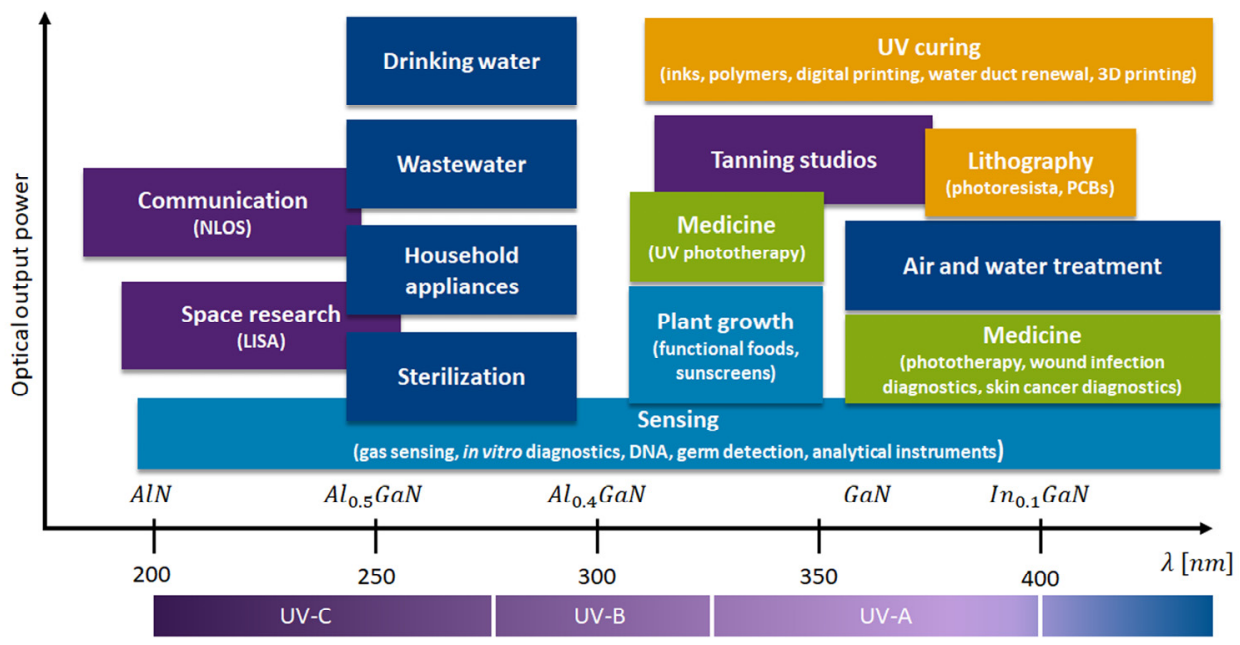

Figure 4. Principal applications for the LEDs in the UV range (Adapted from "The 2020 UV emitter roadmap", H. Amano et al., https:/ / doi.org/10.1088/1361--6463/aba64c, accessed on 15 September 2020 licensed under CC BY 4.0 [30]).

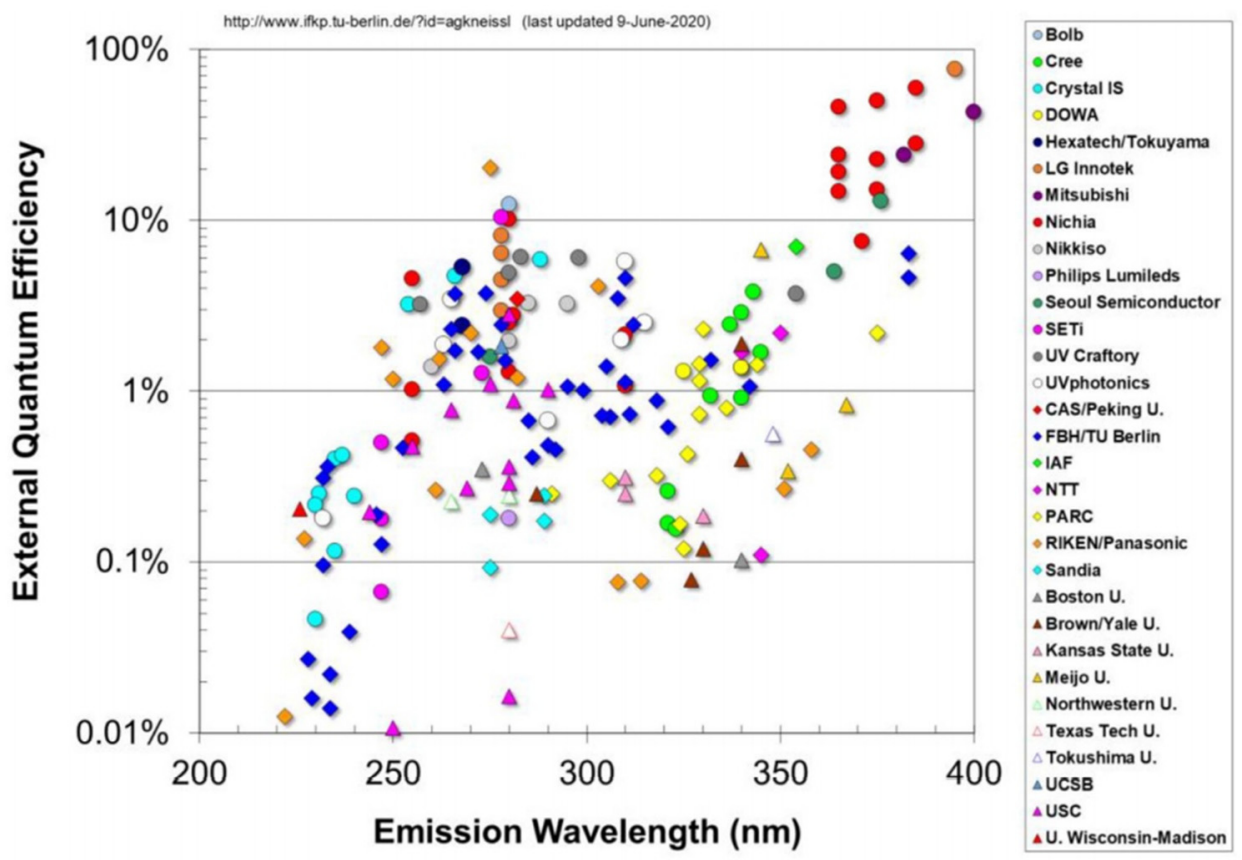

Figure 5. External quantum efficiency of UV LEDs in the spectral range between 200-400 nm (Reprinted from “The 2020 UV emitter roadmap", H. Amano et al., https:/ / doi.org/10.1088/1361-6463/aba64c, accessed on 15 September 2020 licensed under CC BY 4.0 [30]).

Worse efficiency results are reported for UVB LEDs, range where were discovered interesting application in the later years 2000s, such as phototherapy and plant growth. The phototherapy consists in a reconstruction of the solar spectrum from UVB to visible in order to provide treatment of dermatological (vitiligo and psoriasis) [36,37] sleep and psychiatric disorders [38]. Instead for the plant growth, it was demonstrated that a particular range of wavelength (280-315 nm) [39-42] increase flowering, nutrition and growth, in addition to a pesticide effect. The biggest problem for the UVB LEDs is the low EQE, that reach in this range values of about $10 \%$, limited from several factors including all the internal, injection and extraction efficiencies.

Instead, only in the last years, with a big push with the arrival of SARS-CoV2, there was an improvement in the realization technologies of UVC LEDs, where the queen appli- 
cation is the disinfection of surfaces [43-45]. In fact, as demonstrated $[19,21,46]$ the range 240-280 nm is the best to induce modification of DNA and/or RNA in microorganisms, blocking their reproduction also with small optical power densities $\left(>10 \mathrm{~mJ} / \mathrm{cm}^{2}\right)$. Other important applications in this wavelength range could be found in the wastewater and drinking treatments [47-49], that however require higher optical power densities; for this reason, nowadays for these processes are still used mercury UV lamps.

One of the biggest challenges in the UV field is the total replacement of the UV lamps with the UV LEDs; this is desirable because, for the time being, UV LEDs imply lots of advantages in respect to one big disadvantage [50]. About the advantages, a LED chip has a much more compact structure that lead to a much greater design flexibility for UV modules, it provides a lower power consumption and so a lower heat generation, it does not require warm-up times before the use, but it is ready to use at the turn-on, and it is environmentally friendly, since it contains no mercury or produce ozone. Throughout, the biggest advantages are the narrow and the tunable spectrum of the LED, that could be assumed in first order as a single wavelength, instead of the wide emission spectrum from UV to infrared of the UV lamps. On the other hand, the disadvantage is the lower wall-plug efficiency (WPE) of the LEDs in respect to the lamps; it could be expressed as:

$$
W P E=\frac{P_{\text {out }}}{I \cdot V}=E Q E \cdot \frac{h v}{q V}=E Q E \cdot \eta_{\text {el }}
$$

where $P_{\text {out }}$ is the output power, $I$ and $V$ the operating current and voltage, $h v$ the emitted energy of the photons, $\eta_{e l}$ the electrical efficiency, and $E Q E=\eta_{i n j} \cdot \eta_{\text {rad }} \cdot \eta_{e x t}$ where they are respectively the injection, radiative and extraction efficiencies. To reach this goal, higher output power and quantum efficiency should be achieved in the next years, with the research groups that should concentrate their efforts to improve all the single efficiencies.

About the injection efficiency, the main work will be on the study of the structure in order to reduce the electron leakage from the active region [51,52], increase the hole current from the p-side [53], increase the doping efficiency of magnesium, and avoid the generation of defects in the active region that cause bands bending that contrast the injection of carriers [54]. Solutions under investigation consider the realization of graded multi-quantum barrier EBLs [55], that show a higher effectiveness in the block of electron leakage current and, at the same time, do not create energy barriers to the holes moving toward the active region. The radiative efficiency is principally affected by the presence of non-radiative recombination centers (NNRCs) inside the active region, that subtract carriers from the QWs that could generate photons. These NNRCs are usually point defects, vacancies or dislocations present in the material, generated during the growth of the device especially from lattice mismatch between layers or from inactivation of dopants [56,57]. They could not be avoided, but they could be reduced with particular techniques such as the insertion of superlattice underlayer [58], a layer grown to adapt the substrate with the active region. Finally, also the extraction efficiency is a limitation factor for the UV LEDs, because the material used in the construction $(\mathrm{AlGaN})$ presents a high refractive index, that leads to a high internal reflection of the photons that could not escape from the structure. This could be solved with the research of suitable materials for the encapsulation of the LEDs [59], that must be UV transparent and not degrade under UV exposure.

\section{State-of-the-Art Commercial Devices: Performance and Reliability}

In order to favor the penetration of UV LEDs in the market, they must show the important characteristic of stability over lifetime, i.e., they have to ensure several minimal requirements, as a certain emitted optical power for various thousands of functioning hours. At the time being, their lifetime is not comparable with the one of the visible counterparts, but in recent years there was a marked improvement that bring some UVB LEDs to reach lifetime of over 10,000 h (data provided by UV LED manufacturer on device datasheet). On the other hand, UVC LEDs has not demonstrated yet this long lifetime, stopping at a value of about few hundred or thousand hours $[60,61]$. 
The problems that arise during the aging of the devices could be noted from different characteristics in the devices: (i) a decrease in the optical power [54,60,62-64], (ii) the increase in the sub turn-on and reverse leakage currents [62], (iii) changes in the drive voltage $[57,62]$, (iv) changes in the spectral characteristics [60,65], and (v) catastrophic failures [66]. The problems have been a topic of study for research groups for quite some time, and their causes could be summarized as: (i) generation of defects inside the active region [54,60], (ii) decrease in the injection efficiency during the aging [54], (iii) migration of defects or atoms through the heterostructure [65], (iv) activation and/or compensation of doping materials [57], and (v) leakage current paths through defects [62].

Starting from the work proposed by Trivellin et al. [60], it is possible to notice several aspects just discussed. Indeed, from Figure 6 where is reported a constant current stress at $500 \mathrm{~mA}$ on commercial devices with nominal wavelength of $280 \mathrm{~nm}$, it is reported a decrease in the optical power with the aging of the device and the presence and the appearance of parasitic emission bands in the power spectral density. The authors correlated these processes respectively with the generation of defect with increasing stress time, and with the recombination through defects in the active region, in the barriers and in the p-side, where the injection was favored by trap assisted tunneling (TAT) processes through the EBL. These hypotheses were supported by the C-DLTS measurements carried out on the LEDs, where was found a deep level for electrons with activation energy $E_{a}=0.73-0.92 \mathrm{eV}$ and a shallow level for holes with $\mathrm{E}_{\mathrm{a}}=0.18-0.28 \mathrm{eV}$.

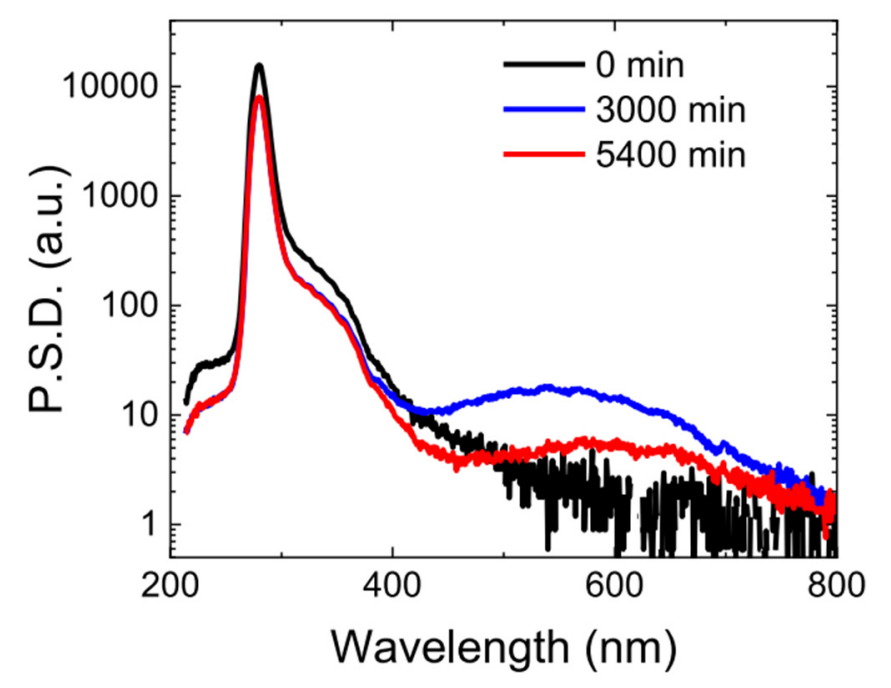

Figure 6. Effects of a constant current stress at $500 \mathrm{~mA}$ on spectral emission of the device at the current of $100 \mathrm{~mA}$ (Copyright (2019) The Japan Society of Applied Physics [60]).

Another important work that shows similar results is the one proposed by Monti et al. [62], where is reported an extensive analysis on non-commercial devices at $310 \mathrm{~nm}$. The paper presented a complete analysis about the presence of parasitic peaks, the degradation mechanisms involved during the stress, and the causes that led to a modification of the current-voltage (I-V) characteristics (Figure 7). The parasitic peak (a band in the range $325-355 \mathrm{~nm}$ ) was ascribed to the increase in radiative recombination through defects in the last layer before the EBL. Two different degradation mechanisms were identified: one in the first $50 \mathrm{~h}$, correlated to the generation of defects near the EBL, and one after $50 \mathrm{~h}$, ascribed to diffusion process in the active region that caused an increase in non-radiative recombination. The mechanism ascribed to the modification of I-V characteristic was: for the reverse leakage current, a generation of point defects inducing parasitic current path across the active region; for the sub-turn on current, an increase of TAT related to the diffusion processes; for the decrease in drive voltage, a change in the electrical properties of p-side. About the decrease in drive voltage during the aging, following work as the one 
of Piva et al. [57] ascribed this behavior to the increase in Mg doping activation caused by the current flow.

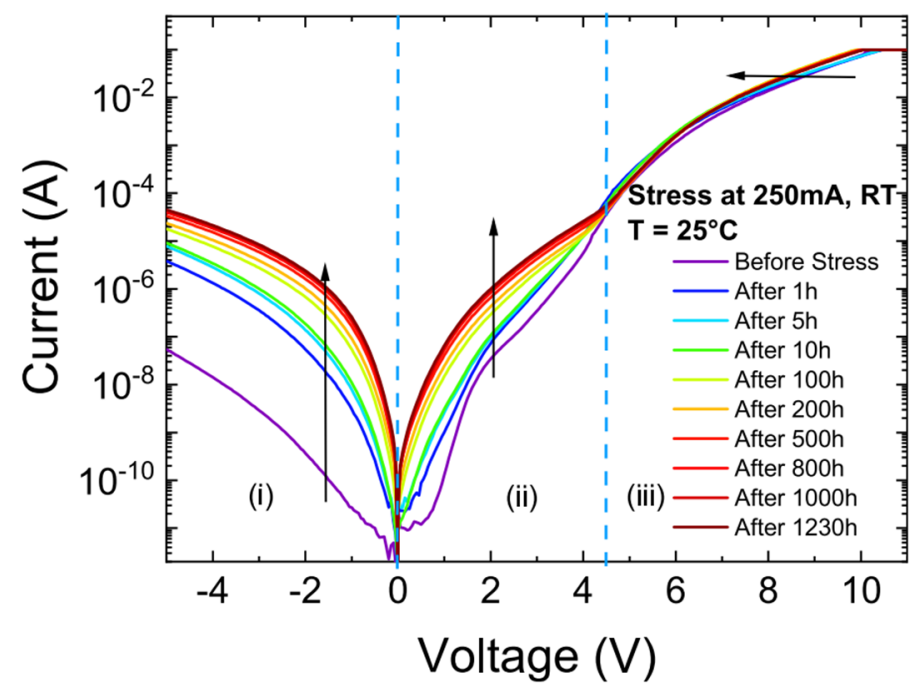

Figure 7. Current-voltage characteristic in semilogarithmic scale of the LED during the constant current stress a $250 \mathrm{~mA}$ (@ 2019 IEEE. Reprinted, with permission, from "High-Current Stress of UV-B (In)AlGaN-Based LEDs: Defect-Generation and Diffusion Processes", D. Monti et al., https: / / doi.org/10.1109/TED.2019.2920521, accessed on 10 July 2019 [62]).

Piva et al. [54] presented a more recent work about the modeling of the mechanisms that afflict the decrease in the optical power during the lifetime of commercial devices. The authors identified two degradation mechanism in their devices, one at high current levels and one at low current levels (Figure 8). The first mechanism was ascribed and modeled with an ordinary differential equations system based on the de-hydrogenation of gallium vacancies in the active region, that led to a generation of negative charge and a following decrease in injection efficiency. Indeed, the second mechanism was ascribed to an increase in non-radiative recombination caused by an increase in defectiveness of active region due to the presence of Auger recombination. This model was initially proposed by Ruschel et al. [64] and was supported by the steady state photocapacitance (SSPC) measurements that showed the generation of mid-gap defect during the aging of the devices.
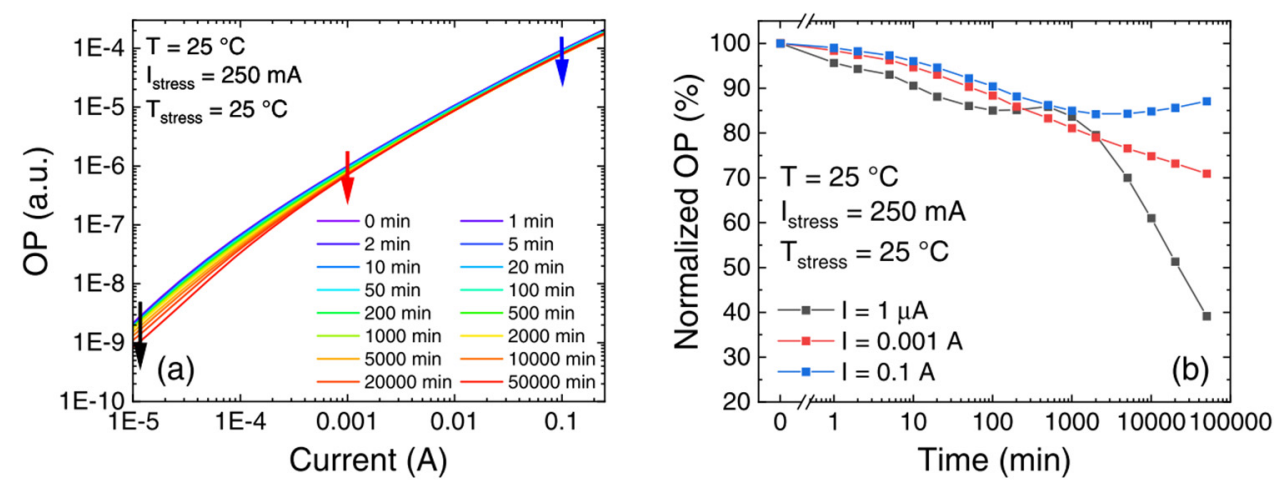

Figure 8. (a) Optical power characteristic (L-I) during the aging. (b) Normalized optical power at three different current levels. The measure shows a similar decrease for all current levels in the first of steps; instead, after $1000 \mathrm{~min}$ there is a higher decrease in optical power for low current levels, caused by the activation of a second degradation mechanism (Reprinted from "Modeling the degradation mechanisms of AlGaN-based UV-C LEDs: from injection efficiency to mid-gap state generation", F. Piva et al., https: / / doi.org/10.1364/PRJ.401785, 30 October 2020 licensed under CC BY 4.0 [54]). 
To conclude, we mention the recent work by Glaab et al. [65], where the authors studied the diffusion of hydrogen ions during the lifetime of a UVB LED (Figure 9). They identified a first decrease in the first $10 \mathrm{~h}$ in $\mathrm{H}$ concentration in the $\mathrm{p}$-side and in the active region, caused by a migration of $\mathrm{H}$ towards the $\mathrm{n}$-side. This effect was due to the break of H-containing defect complexes, possibly caused by the interaction with hot carriers. After that, the hydrogen continued to migrate toward n-side, and changes in the optical power and drive voltage were observed, related to the point defects generated in the active region and in the p-side.

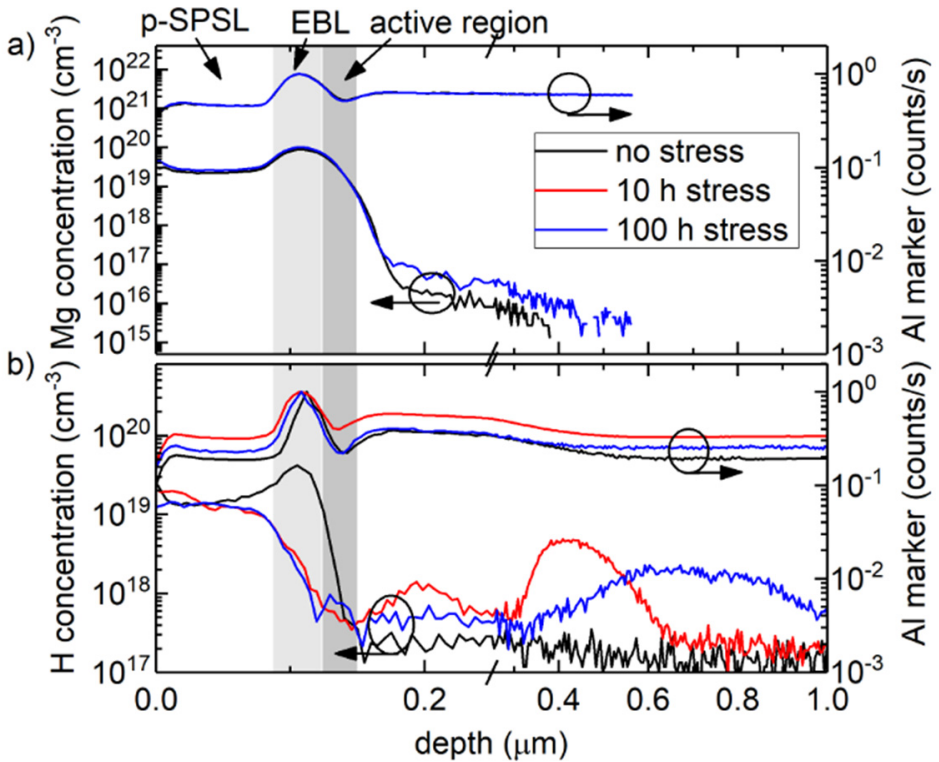

Figure 9. (a) Mg and (b) $\mathrm{H}$ concentration depth profiles at 0, 10 and $100 \mathrm{~h}$ of operation determined by SIMS (@ 2019 IEEE. Reprinted, with permission, from “Degradation of (In)AlGaN-Based UVB LEDs and Migration of Hydrogen", J. Glaab et al., https:/ / doi.org/10.1109/LPT.2019.2900156, 19 February 2019 [65]).

To summarize, the performance of the UV LEDs is increasing year after year, showing a good stability at the working condition for longer and longer lifetime. From the point of view of reliability, the stability may be afflicted by some issues, that have been identified and are under study. In order to provide a better understanding of these problematics, an extensive research work should be done in the next years, continuing to analyze the current issues and introducing new experimental methodologies.

\section{UV Disinfection for SARS-CoV2: Previous Reports}

In this section we summarize previous peer reviewed published works which report viral inactivation of SARS-CoV-2 on surfaces by using ultraviolet radiation, in particular emitted by LEDs. The objective is to try to identify an effective dose-effect response of the virus at a specific wavelength. Since LEDs are available in different wavelengths, differently from traditional discharge lamps which have a fixed emission wavelength, the wavelength-effect response will also be considered in order to identify the most effective wavelength. When comparing viral inactivation results of different scientific reports, care should be taken in considering the different effects of surface, temperature, viral strain, carrier and so on.

Inagaki et al. [46] tested the antiviral efficacy of irradiation by DUV-LED, emitting UV radiation at a wavelength of $280 \mathrm{~nm} \pm 5 \mathrm{~nm}$, against SARS-CoV-2. For the evaluation of DUV-LED inactivation, aliquots of $150 \mu \mathrm{L}$ of virus stock $\left(3.7 \times 10^{4} \mathrm{PFU} / \mathrm{mL}\right)$ were placed in the center of a $60-\mathrm{mm}$ Petri dish and irradiated with $3.75 \mathrm{~mW} / \mathrm{cm}^{2}$ at work distance $20 \mathrm{~mm}$ for a range of times $(\mathrm{n}=3$ each time for $1 \mathrm{~s}, 10 \mathrm{~s}, 20 \mathrm{~s}, 30 \mathrm{~s}$, or $60 \mathrm{~s}$, and each dose corresponding to $3.75 \mathrm{~mJ} / \mathrm{cm}^{2}, 37.5 \mathrm{~mJ} / \mathrm{cm}^{2}, 75 \mathrm{~mJ} / \mathrm{cm}^{2}, 112.5 \mathrm{~mJ} / \mathrm{cm}^{2}$ or $225 \mathrm{~mJ} / \mathrm{cm}^{2}$, 
respectively). The infectious titer reduction ratio of $87.4 \%$ was obtained with irradiation for $1 \mathrm{~s}$, and the rate increased up $99.9 \%$ with irradiation for $10 \mathrm{~s}$.

Heilingloh et al. [67] investigated the susceptibility of high titer viral stocks of SARSCoV-2 to combined or separate UVA and/or UVC irradiation. In order to do that, a viral stock at a concentration of $5 \times 10^{6} \mathrm{TCID}_{50} / \mathrm{mL}$ was irradiated with UV light for up to $30 \mathrm{~min}$. The Median Tissue Culture Infectious Dose assay permits to calculate the viral dilution at which $50 \%$ of the model cell culture show a cytopathic effect (CPE). UV exposure was performed by separate or combined irradiation with UVC $(254 \mathrm{~nm})$ and/or UVA $(365 \mathrm{~nm})$ of $600 \mu \mathrm{L}$ virus stock in 24 -well plates. The UV light source was a mercury-lamp capable of emitting both UVC and UVA radiation and was placed at a distance of $3 \mathrm{~cm}$ above the bottom of the plate. Complete virus inactivation was achieved after a 9 min exposure to UVC and an emitted UVC dose of $1048 \mathrm{~mJ} / \mathrm{cm}^{2}$. Total inactivation of SARS-CoV-2 was also achieved after 9 min of combined UVA and UVC exposure. UVA exposure alone was less effective on virus inactivation. After 9 min of irradiation and an emitted dose of $292 \mathrm{~mJ} / \mathrm{cm}^{2}, 1 \log$ unit reduction of the viral load was observed.

Borman et al. [68] investigated the effectiveness of two commercial UVC-LED disinfection boxes, available for private use, in inactivating SARS-CoV-2-contaminated surfaces such as glass, metal, and plastics typically used on personal items. Box 1 had lateral UVC-LEDs and box 2 had UVC-LEDs incorporated in the lid of the box. A mirror was installed to the bottom of the chamber. For box 1, the peak wavelength emission was measured at around $254 \mathrm{~nm}$. For box 2, the peak wavelength emission was detected at $280 \mathrm{~nm}$. Metal, glass or plastic samples were overlaid with SARS-CoV-2. The SARS-CoV-2 stocks were diluted with an organic matrix mimicking respiratory secretions, resulting in a final virus concentration of the samples of $4.5 \times 10^{6} \mathrm{TCID}_{50} / \mathrm{mL}$ for the experiments in box 1 and $1.8 \times 10^{6} \mathrm{TCID}_{50} / \mathrm{mL}$ for the experiments in box 2 . Regardless of the used box and the materials, SARS-CoV-2 could be almost completely inactivated after 3 min exposure (box 1: $1 \mathrm{~cm}: 44.1 \mathrm{~mJ} / \mathrm{cm}^{2}, 5 \mathrm{~cm}: 11.7 \mathrm{~mJ} / \mathrm{cm}^{2}$; box 2: $1 \mathrm{~cm}: 21.06 \mathrm{~mJ} / \mathrm{cm}^{2}$ ). Even $10 \mathrm{~s}$ of exposure strongly reduced viral loads on the contaminated surfaces. The mirror at the bottom of box 2 may have contributed to facilitate the inactivation of the virus.

Liu et al. [69] fabricated a UVC sterilization light source which makes use of DUVLEDs with emission wavelength of $275 \mathrm{~nm}$, designed ad hoc for this application. They obtained a typical emission power of $10 \mathrm{~mW}$ at $100 \mathrm{~mA}$ for chip size of $10 \mathrm{mil} \times 20 \mathrm{mil}$. Those chips were integrated into the UVC source with a chip array of $15 \times 13$ at a size of $3.0 \times 3.6 \mathrm{~cm}^{2}$, with a typical emitting power of $2 \mathrm{~W}$ at a current of $1.3 \mathrm{~A}$. The array was composed of 13 parallel connected units and each unit includes 15 DUV-LEDs in series connection. Nanopatterned sapphire substrates (NPSSs) are used to prepare the AlN template by metal-organic chemical vapor deposition (MOCVD) with an epitaxial lateral overgrowth (ELOG) process. An external quantum efficiency (EQE) of $2.65 \%$ at a forward current of $20 \mathrm{~mA}$ is obtained. The IQE is estimated to be about $60 \%$. The LED array is integrated on thermo-conductive AlN ceramics equipped with a fan air-cooling system, in order to take care of the heat accumulation in the case of high-power working regime. The SARS-CoV-2 samples $\left(100 \mathrm{CCID}_{50} / 0.05 \mathrm{~mL}\right.$ ) were treated with UVC light source with an exposure time of $1 \mathrm{~s}$ and a power density of $94 \mathrm{~mW} / \mathrm{cm}^{2}$ (radiation dose of $94 \mathrm{~mJ} / \mathrm{cm}^{2}$ ). Then irradiated and not irradiated samples were used to inoculate Vero cell cultures. It was concluded that the treatment with an exposure time of $1 \mathrm{~s}$ enables $100 \%$ elimination of the SARS-CoV-2 at the cellular level.

Gerchman et al. [19] examined the efficiency of UV LEDs at different wavelengths on inactivation of the human Coronavirus OC43 (HCoV-OC43), used as SARS-CoV-2 surrogate, to develop a dose-response curve for UV LED at various wavelengths. Two UV LED systems were used: one included LEDs with peak emission wavelengths at $279 \mathrm{~nm}$ and $297 \mathrm{~nm}$, while the other one included LEDs with peak emission wavelengths at $267 \mathrm{~nm}$ and $286 \mathrm{~nm}$. The UV LEDs at 267 and $279 \mathrm{~nm}$ were very effective at inactivating the Coronavirus (3-log unit inactivation at irradiation 6 and $7 \mathrm{~mJ} / \mathrm{cm}^{2}$, respectively), whereas longer UV-LED wavelengths (i.e., $286 \mathrm{~nm}$ and $297 \mathrm{~nm}$ ) required higher doses for 3-log unit 
inactivation $\left(13 \mathrm{~mJ} / \mathrm{cm}^{2}\right.$ and $32 \mathrm{~mJ} / \mathrm{cm}^{2}$, respectively). None of the wavelength tested showed a tailing effect.

Kitagawa el al. [70] investigated the titer of SARS-CoV-2 after UV irradiation at $222 \mathrm{~nm}$ using the $50 \%$ tissue culture infectious dose $\left(\mathrm{TCID}_{50}\right)$ assay. The Care222 (Ushio Inc., Tokyo, Japan) UVC emitting device used in this study was a 222-nm krypton-chloride $(\mathrm{Kr}-\mathrm{Cl})$ excimer lamp module. The lamp contains an optical filter that removes essentially all but the dominant 222-nm emission wavelength. For 222-nm UVC irradiation, the lamp was placed $24 \mathrm{~cm}$ above the surface of the plates and the radiation intensity at the surface of the plates was $0.1 \mathrm{~mW} / \mathrm{cm}^{2}$. Under $1 \mathrm{~mJ} / \mathrm{cm}^{2}$ and $3 \mathrm{~mJ} / \mathrm{cm}^{2}$ of $222-\mathrm{nm}$ UVC irradiation ( $0.1 \mathrm{~mW} / \mathrm{cm}^{2}$ for $10 \mathrm{~s}$ and $\left.30 \mathrm{~s}\right)$, SARS-CoV-2 inactivation of $\sim 88.5$ and $99.7 \%$, were respectively observed. In contrast, the copy number of SARS-CoV-2 RNA did not change after UVC irradiation even after a 5-min irradiation.

Sabino et al. [71] developed a controlled assay to investigate the UV-C inactivation kinetics of SARS-CoV-2 and established the UV-C lethal doses in vitro. For this study, a low-pressure mercury lamp emitting UVC radiation at $254 \mathrm{~nm}$ was used. An aliquot of the SARS-CoV-2 stock was thawed and $100 \mu \mathrm{L}$ were diluted in $900 \mu \mathrm{L}$ of DMEM-HG without supplementation. Then, samples of $200 \mu \mathrm{L}$ of this dilution was placed in wells of a 24-well microtiter plate, and were exposed to the lamp placed $30 \mathrm{~cm}$ above the plate to allow a uniform irradiance over the plate wells $\left(2.2 \pm 0.2 \mathrm{~mW} / \mathrm{cm}^{2}\right)$. Light was delivered by $2 \mathrm{~s}, 30 \mathrm{~s}$ and $120 \mathrm{~s}$ corresponding to doses of $4.4,66$ and $264 \mathrm{~mJ} / \mathrm{cm}^{2}$, respectively. After irradiation, samples were used to inoculate Vero cell culture and viral RNA was quantified through RT-qPCR technique. LD90 was achieved upon very short irradiation $0.01 \mathrm{~s}\left(0.016 \mathrm{~mJ} / \mathrm{cm}^{2}\right)$.

Biasin et al. [23] evaluated the antiviral effect of low pressure mercury vapor lamp providing an average intensity of $1.082 \mathrm{~mW} / \mathrm{cm}^{2}$ over the illumination area; different irradiation doses $\left(3.7 \mathrm{~mJ} / \mathrm{cm}^{2}, 16.9 \mathrm{~mJ} / \mathrm{cm}^{2}\right.$, and $\left.84.4 \mathrm{~mJ} / \mathrm{cm}^{2}\right)$ and viral load $(0.05 \mathrm{MOI}$, 5 MOI, and 1000 MOI, Multiplicity of Infection) of SARS-CoV-2 have been tested. The antiviral effect of UVC radiation is evident for all the tested viral titers and a dose-response effect has been observed. UV-C dose of just $3.7 \mathrm{~mJ} / \mathrm{cm}^{2}$ was sufficient to achieve a more than 3-log unit inactivation without any sign of viral replication. Moreover, a complete antiviral effect has been observed with $16.9 \mathrm{~mJ} / \mathrm{cm}^{2}$.

Minamikawa et al. [72] quantified the irradiation dose of DUV-LED necessary to inactivate SARS-CoV-2. In order to do that, they determined the culture media suitable for the irradiation of SARS-CoV-2 and optimized the irradiation apparatus using DUV-LEDs available on the market that operate at a center wavelength of $265 \mathrm{~nm}, 280 \mathrm{~nm}$ or $300 \mathrm{~nm}$. For quantitative evaluations of the DUV-LED irradiation effects on SARS-CoV-2, they addressed to minimize DUV-LED light absorbance by the culture media during irradiation. The results indicated that the culture media suitable for DUV-LED irradiation should contain a minimum amount of EMEM and FBS to significantly reduce the light absorbance. The DUV-LED irradiation apparatus is composed of a DUV-LED unit, a 96-well microplate as a virus medium chamber, and chamber alignment jigs. The DUV-LED unit consists of two DUV-LED chips and a heat sink. Upon irradiation, the virus medium chamber was set just under the DUV-LED unit. Virus inoculum was placed in a defined well of the chamber and was irradiated by the DUV-LED from the top. The DUV-LED irradiation area was set large enough to obtain uniform irradiation. For correct irradiation, the virus medium chamber is fixed by chamber alignment jigs at both sides. This apparatus was constructed for the DUV-LEDs operating at the same peak wavelengths as previously reported. At all wavelengths, the plaque numbers decreased exponentially with respect to the total dose of DUV-LED energy. The DUV-LED operating at a wavelength of $265 \mathrm{~nm}$ exhibited the highest inactivation effect on SARS-CoV-2. To achieve the $99.9 \%$ inactivation of SARS-CoV-2, the total doses of DUV-LED energy required were found to be $1.8 \mathrm{~mJ} / \mathrm{cm}^{2}$ for $265 \mathrm{~nm}, 3.0 \mathrm{~mJ} / \mathrm{cm}^{2}$ for $280 \mathrm{~nm}$, and $23 \mathrm{~mJ} / \mathrm{cm}^{2}$ for $300 \mathrm{~nm}$.

Trivellin et al. [73] designed a sanitization system based on $280 \mathrm{~nm}$ LEDs and specifically designed to inactivate SARS-CoV-2 on spherical objects, like sport balls, a total of 
56 LEDs each emitting $10 \mathrm{~mW}$ has been used on a spherical surface of $25 \mathrm{~mm}$ of diameter. The result achieved indicate that a $99.9 \%$ inactivation can be reached after 1 min of treatment with a dose of $83.1 \mathrm{~J} / \mathrm{m}^{2}$ independently on the types of material and its size. It is reported that objects with any convex shape can be correctly irradiated.

Although most of the reported works do not specifically report the Full Width at Half Maximum (FWHM) of the LED radiation, typically it is comprised between $10 \mathrm{~nm}$ and $20 \mathrm{~nm}$.

To summarize the results Table 2 and two different plots have been created. The first plot is reported in Figure 10, it reports on the dose required to achieve a 3 log unit inactivation, corresponding to a decrease of $99.9 \%$ of the viral titer, for different wavelengths in the range $254-300 \mathrm{~nm}$. Reports where a $3 \log$ unit inactivation was not reached have been discarded. It is interesting to notice that the better results are achieved at wavelengths compatible with the DNA interaction reported for Bacillus subtilis spores in Figure 3, around $254-270 \mathrm{~nm}$. However, the collected data indicate that a $\log 3$ reduction is still possible with a higher dose as the energy of the photons decreases.

Table 2. Summary of the SARS-CoV-2 antiviral effect of UVC light from different types of sources.

\begin{tabular}{|c|c|c|c|c|c|}
\hline Tech. & $\lambda(\mathbf{N m})$ & Dose $\left(\mathrm{Mj} / \mathrm{Cm}^{2}\right)$ & Log Reduction & Notes & Ref. \\
\hline LED & $280 \pm 5$ & $\begin{array}{c}3.75 \\
37.5 \\
75 \\
112.5 \\
225\end{array}$ & $\begin{array}{c}0.9 \\
3.1 \\
>3.3 \\
>3.3 \\
>3.3\end{array}$ & $\begin{array}{l}\text { Aliquots of virus stock }(150 \mu \mathrm{L}) \\
\text { were placed in the centre of a } 60 \mathrm{~mm} \\
\text { Petri dish and irradiated with } \\
3.75 \mathrm{~mW} / \mathrm{cm}^{2} \text { at a work distance of } \\
20 \mathrm{~mm} \text { for a range of times }\end{array}$ & [46] \\
\hline Tubes & $\begin{array}{l}254 \\
365\end{array}$ & $\begin{array}{c}1048 \\
292\end{array}$ & $\begin{array}{c}>4 \\
1\end{array}$ & $\begin{array}{c}\text { A viral stock at a concentration of } \\
5 \times 10^{6} \mathrm{TCID} \mathrm{T}_{50} / \mathrm{mL} \text { was irradiated } \\
\text { with UV light up to } 30 \mathrm{~min} ; \\
\text { UV exposure was performed by } \\
\text { separate or combined irradiation } \\
\text { with UVC and/or UVA of } 600 \mu \mathrm{L} \\
\text { virus stock in } 24 \text {-well plates }\end{array}$ & [67] \\
\hline LED & $\begin{array}{l}254 \\
280\end{array}$ & $\begin{array}{c}11.7 \\
39 \\
44.1 \\
147 \\
21.06 \\
70.2 \\
10 \text { min, } 4 \text { cm dist. }\end{array}$ & $\begin{array}{c}0.93 \text { (glass, metal) } \\
1 \text { (plastic) } \\
1.1 \text { (glass) } \\
1.13 \text { (plastic) } \\
1.83 \text { (metal) } \\
>4 \text { (glass, plastic) } \\
>4 \text { (glass, plastic, metal) } \\
1.6 \text { (glass) } \\
1.9 \text { (plastic) } \\
2.1 \text { (metal) } \\
1.67 \text { (glass) } \\
2.23 \text { (metal) } \\
2.27 \text { (plastic) } \\
>4 \text { (glass, plastic, metal) }\end{array}$ & $\begin{array}{l}\text { A measurement of the emitted } \\
\text { light intensity at } 4 \mathrm{~cm} \text { distance } \\
\text { would have required drilling a } \\
\text { hole into the bottom of the box, } \\
\text { damaging the box; } \\
\text { different materials (glass, metal, } \\
\text { plastic) tested as carriers for } \\
\text { viral contamination; } \\
\text { the carriers were positioned at } \\
\text { different distances from } \\
\text { the UVC-LEDs }\end{array}$ & [68] \\
\hline LED & 275 & 94 & $>4$ & $\begin{array}{c}\text { To obtain a high output power } \\
\text { density, the UVC LED chips are } \\
\text { integrated into an array of } \\
15 \times 13 \text {, with a whole area of } \\
\quad 3 \times 3.6 \mathrm{~cm}^{2}\end{array}$ & [69] \\
\hline LED & $\begin{array}{l}267 \\
279 \\
286 \\
297\end{array}$ & $\begin{array}{c}6 \\
7 \\
13 \\
32\end{array}$ & $\begin{array}{l}3 \\
3 \\
3 \\
3\end{array}$ & $\begin{array}{l}\text { The human Coronavirus OC43 } \\
\text { (HCoV-OC43) was used as a } \\
\text { surrogate to the SARS-CoV-2; } \\
\text { for each irradiation experiment } \\
50 \mu \mathrm{L} \text { of virus suspension was } \\
\text { placed in each well of a black } \\
\text { 24-well plate }\end{array}$ & [19] \\
\hline
\end{tabular}


Table 2. Cont.

\begin{tabular}{|c|c|c|c|c|c|}
\hline Tech. & $\lambda(\mathrm{Nm})$ & Dose $\left(\mathrm{Mj} / \mathrm{Cm}^{2}\right)$ & Log Reduction & Notes & Ref. \\
\hline Tubes & 222 & 3 & $\sim 2.5$ & $\begin{array}{l}\text { Viral suspension }(100 \mu \mathrm{L}) \\
\text { containing ca. } 5 \times 10^{6} \mathrm{TCID}_{50} / \mathrm{mL} \\
\text { were loaded onto a sterile } \\
\text { polystyrene plate ( } 9 \mathrm{~cm} \text { diameter) } \\
\text { and spread into a circle of approx. } \\
7 \mathrm{~cm} \text {. The inoculum was allowed } \\
\text { to dry under sterile laminar flow } \\
\text { in a biosafety cabinet at } \\
\text { room temperature; } \\
\text { in contrast to the viable } \\
\text { SARS-CoV-2, the copy number of } \\
\text { SARS-CoV-2 RNA determined by } \\
\text { RT-qPCR was not reduced even } \\
\text { after } 30 \mathrm{~mJ} / \mathrm{cm}^{2} \text { of } 222 \text { nm } \\
\text { UVC irradiation }\end{array}$ & {$[70]$} \\
\hline Tubes & 254 & $\begin{array}{c}0.016 \\
0.706 \\
6.556 \\
31.88 \\
108.714\end{array}$ & $\begin{array}{l}1 \\
2 \\
3 \\
4 \\
5\end{array}$ & $\begin{array}{c}\text { within less than a second, UVC } \\
\text { irradiation was able to inactivate } \\
\text { more than } 99 \% \text { of SARS-CoV-2 } \\
\text { viral particles }\end{array}$ & {$[71]$} \\
\hline Tubes & 254 & $\begin{array}{c}3.7 \\
16.9 \\
84.4\end{array}$ & $\begin{array}{l}3 \\
6 \\
6\end{array}$ & $\begin{array}{c}\text { different virus concentration } \\
\text { were tested; } \\
\text { a dose of } 3.7 \mathrm{~mJ} / \mathrm{cm}^{2} \text { was not } \\
\text { enough for a high virus } \\
\text { concentration and a dose of } \\
16.9 \mathrm{~mJ} / \mathrm{cm}^{2} \text { was required in } \\
\text { order to avoid virus replication }\end{array}$ & [23] \\
\hline LED & $\begin{array}{l}265 \\
280 \\
300\end{array}$ & $\begin{array}{c}1.8 \\
3 \\
23\end{array}$ & $\begin{array}{l}3 \\
3 \\
3\end{array}$ & $\begin{array}{l}\text { for each irradiation experiment, } \\
100 \mu \mathrm{L} \text { of virus inoculum was } \\
\text { placed in a defined well (E4) of a } \\
\text { 96-well plate, and the plate was } \\
\text { exposed to the designated } \\
\text { irradiation wavelength and time }\end{array}$ & {$[72]$} \\
\hline LED & 275 & 8.31 & 3 & $\begin{array}{l}\text { Analysis carried out on different } \\
\text { surfaces of sport balls }\end{array}$ & {$[73]$} \\
\hline
\end{tabular}

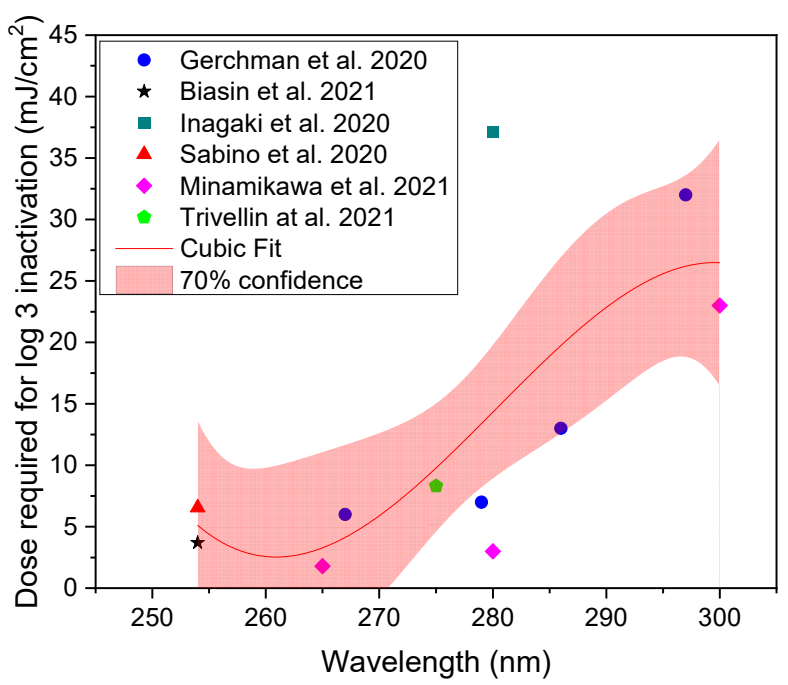

Figure 10. Dose required to reach a $\log 3$ inactivation as a function of wavelength; dots: raw data, red line: cubic fit, red area: $70 \%$ confidence of cubic fit $[19,23,46,71-73]$. 
The second summary plot is reported in Figure 11, it reports the log reduction as a function of the irradiation dose for UVC LEDs with a peak wavelength of $280 \pm 5 \mathrm{~nm}$. The viral inactivation is dose related, but the reports results show a certain variability as a function of the procedure and support material. From this graph it is evident that a dose below $40 \mathrm{~mJ} / \mathrm{cm}^{2}$ can be sufficient to achieve a detectable reduction in the SARS-CoV-2 viral titer in all the reported data. Three previous works also achieved a 3 log unit reduction with an irradiance below $10 \mathrm{~mJ} / \mathrm{cm}^{2}$.

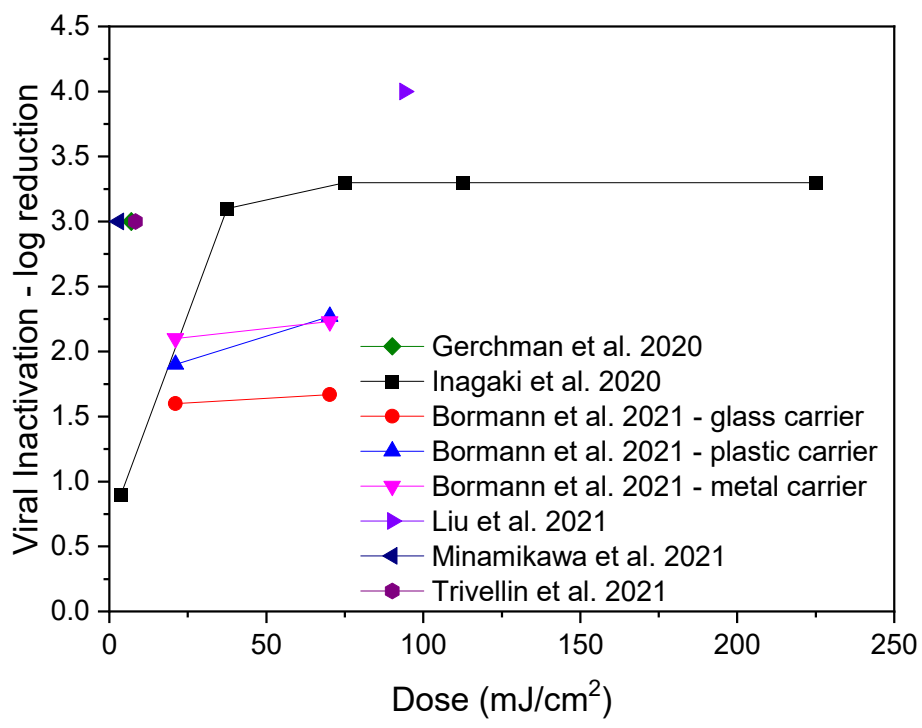

Figure 11. SARS-CoV-2 reduction as a function of the irradiation dose for UVC LEDs with a peak wavelength of $280 \mathrm{~nm} \pm 5 \mathrm{~nm}$, some of the results are verified on different carrier materials $[19,46,68,69,72,73]$.

\section{UV Disinfection for SARS-CoV2: Challenges and Perspectives for Massive Adoptions}

Adoption of viral inactivation systems based on different technologies, including UVC radiation has grown recently and is expected to still grow in next period, for example as suggested by WHO in their guidelines [2,74] air and surface sanitization systems are suggested to be placed on work premises and public areas.

\subsection{Environmental Issues}

UVC light sources based on discharge lamps are based on mercury for the emission of their high energy radiation. Mercury is a well-known pollutant [26] and the mass adoption use of such lamps has an inherent environmental risk related to their disposal. The issue is analogous to the pollution caused by mercury contained inside fluorescent lamps, which can reach up to $40 \mathrm{mg}$ per lamp. It has been reported that in China up to $20 \%$ of mercury present in fresh water was caused by fluorescent lamps [75]. With a content of up to $100 \mathrm{mg}$ per device [76], UVC low pressure vapor lamps are an even more relevant cause of concern if mass adoption is established as a consequence of the pandemic and future safety and prevention actions. AlGaN based Ultraviolet LEDs are instead environmentally safe and do not require any special treatment at the end of their useful life. Even if their efficiency is currently lower, the mass adoption of devices based on solid state technology is therefore a safer bet for a more ecologically sustainable future.

\subsection{Development of Technology to Fight Future Pandemics}

A lot of debate has arisen on the cause of the COVID-19 pandemic, from climate change [77] to government actions and lack of adequate healthcare resources [78]. It is however quite clear that: at the current state of population density, environmental changes, travel capabilities, and economical diversity between countries, the risk of other pandemics and health disasters will remain a constant threat. It is then required that an international 
cooperation and joint efforts are put in place by countries worldwide to scale up in particular prevention efforts, some of them being technology dependent. As suggested by Mazzoleni et al. [79] expenses in the healthcare system should be considered an investment for the future and not a cost, with this in mind, the development of technologies which can allow an easier and more efficient prevention of future pandemics should be seen not only as a growing business, but also as a humanity necessity. Even with strongly different technological challenge it is worth comparing the development and performance of commercial InGaN Blue LEDs (WPE higher than 80\%) with AlGaN $280 \mathrm{~nm}$ LEDs (WPE in the range of $1-3 \%$ [80]. The staggering difference between the two shows the impact of mass adoption and market driven development of the technology. In the case of deep UV based LEDs a higher efficiency can on one hand simplify the adoption of portable disinfection and sanitization systems, like UVC equipped masks [16,81], and reduce the cost per watt, which in turn will allow a faster and easier technological implementation of new products.

\section{Conclusions}

While the SARS-CoV-2 pandemic is still an emergency, several research groups have identified an antiviral effect of ultraviolet light. It becomes fundamental to identify the best sanitizing technologies available to help the fight against the pandemic, but also their correct use in order to provide a reference guide for the development of new systems. AlGaN LEDs, are currently available on the market, and their UV radiation is considered effective, unfortunately their lifetime and efficacy are still limited and potentially impacting their mass adoption. With this work we summarized the main results available in the peer-reviewed literature and tried to identify a trend both in the status of the technology and in the antiviral effects of the UV radiation.

From the reported results we can conclude that while the performance of the UV LEDs is still quite far from the target provided by the traditional discharge lamps, their gradual year by year efficiency increase made them suitable for surface and air disinfection systems. Their reliability is still below the expectations, but will be improved in the next years by controlling the generation of defects in the semiconductor, the Auger recombination, and the hydrogen diffusion.

As a final remark we report that the highest antiviral effect is achieved at low doses of light at around $260 \mathrm{~nm}$, similar results have been achieved at $280 \mathrm{~nm}$ with a dose two to three times higher. The current state of technology and research poses then the LEDs with an emission in the range of $275-285 \mathrm{~nm}$ as the most effective for the inactivation of SARS-CoV-2 thanks to their balance between radiative efficacy and emission wavelength.

Author Contributions: Conceptualization, N.T., F.P. and M.M.; data curation, N.T., F.P. and M.M.; writing-original draft preparation, N.T.; writing—review and editing, N.T., F.P., D.F., M.B., C.D.S. V.T.O., F.D., G.M., E.Z. and M.M.; supervision, N.T. and M.M. All authors have read and agreed to the published version of the manuscript.

Funding: This research received no external funding.

Conflicts of Interest: The authors declare no conflict of interest.

\section{References}

1. Zhu, N.; Zhang, D.; Wang, W.; Li, X.; Yang, B.; Song, J.; Zhao, X.; Huang, B.; Shi, W.; Lu, R.; et al. A Novel Coronavirus from Patients with Pneumonia in China, 2019. N. Engl. J. Med. 2020, 382, 727-733. [CrossRef]

2. WHO. COVID-19 Weekly Epidemiological Update 35; World Health Organization: Geneva, Switzerland, 2020 ; pp. 1-3.

3. Grint, D.J.; Wing, K.; Williamson, E.; McDonald, H.I.; Bhaskaran, K.; Evans, D.; Evans, S.J.W.; Walker, A.J.; Hickman, G.; Nightingale, E.; et al. Case fatality risk of the SARS-CoV-2 variant of concern B.1.1.7 in England, 16 November to 5 February. Eurosurveillance 2021, 26, 2100256. [CrossRef]

4. Jain, V.K.; Iyengar, K.P.; Garg, R.; Vaishya, R. Elucidating reasons of COVID-19 re-infection and its management strategies. Diabetes Metab. Syndr. Clin. Res. Rev. 2021, 15, 1001-1006. [CrossRef]

5. Stadnytskyi, V.; Bax, C.E.; Bax, A.; Anfinrud, P. The airborne lifetime of small speech droplets and their potential importance in SARS-CoV-2 transmission. Proc. Natl. Acad. Sci. USA 2020, 117, 11875-11877. [CrossRef] 
6. Wang, J.; Du, G. COVID-19 may transmit through aerosol. Irish J. Med. Sci. 2020, 189, 1143-1144. [CrossRef]

7. Centers for Disease Control and Prevention Guideline for Disinfection and Sterilization in Healthcare Facilities, 2008; Miscellaneous Inactivating Agents; CDC Website: Atlanta, GA, USA, 2013; pp. 9-13.

8. Spaulding, E.H. Alcohol as a Surgical Disinfectant: Pros and cons of a much discussed topic. AORN J. 1964, 2, 67-71. [CrossRef]

9. Seymour Stanton Block. Disinfection, Sterilization, and Preservation, 4th ed.; Lea \& Febiger: Philadelphia, PA, USA, 1991; ISBN1 10: 0812113640. ISBN2 13: 9780812113648.

10. Rutala, W.A.; Weber, D.J. Uses of inorganic hypochlorite (bleach) in health-care facilities. Clin. Microbiol. Rev. 1997, 10, 597-610. [CrossRef] [PubMed]

11. Goldust, M.; Abdelmaksoud, A.; Navarini, A.A. Hand disinfection in the combat against COVID-19. J. Eur. Acad. Dermatol. Venereol. 2020, 34, e454-e455. [CrossRef]

12. Al-Sayah, M.H. Chemical disinfectants of COVID-19: An overview. J. Water Health 2020, 18, 843-848. [CrossRef] [PubMed]

13. Kampf, G.; Todt, D.; Pfaender, S.; Steinmann, E. Persistence of coronaviruses on inanimate surfaces and their inactivation with biocidal agents. J. Hosp. Infect. 2020, 104, 246-251. [CrossRef] [PubMed]

14. Hudson, J.B.; Sharma, M.; Vimalanathan, S. Development of a Practical Method for Using Ozone Gas as a Virus Decontaminating Agent. Ozone Sci. Eng. 2009, 31, 216-223. [CrossRef]

15. Dubuis, M.-E.; Dumont-Leblond, N.; Laliberté, C.; Veillette, M.; Turgeon, N.; Jean, J.; Duchaine, C. Ozone efficacy for the control of airborne viruses: Bacteriophage and norovirus models. PLoS ONE 2020, 15, e0231164. [CrossRef]

16. Lee, J.; Bong, C.; Lim, W.; Bae, P.K.; Abafogi, A.T.; Baek, S.H.; Shin, Y.B.; Bak, M.S.; Park, S. Fast and Easy Disinfection of Coronavirus-Contaminated Face Masks Using Ozone Gas Produced by a Dielectric Barrier Discharge Plasma Generator. Environ. Sci. Technol. Lett. 2021, 8, 339-344. [CrossRef]

17. Cutler, T.D.; Zimmerman, J.J. Ultraviolet irradiation and the mechanisms underlying its inactivation of infectious agents. Anim. Health Res. Rev. 2011, 12, 15-23. [CrossRef] [PubMed]

18. Kowalski, W. Ultraviolet Germicidal Irradiation Handbook; Springer: Berlin/Heidelberg, Germany, 2009; ISBN 978-3-642-01998-2.

19. Gerchman, Y.; Mamane, H.; Friedman, N.; Mandelboim, M. UV-LED disinfection of Coronavirus: Wavelength effect. J. Photochem. Photobiol. B Biol. 2020, 212, 112044. [CrossRef]

20. Chen, R.Z.; Craik, S.A.; Bolton, J.R. Comparison of the action spectra and relative DNA absorbance spectra of microorganisms: Information important for the determination of germicidal fluence (UV dose) in an ultraviolet disinfection of water. Water Res. 2009, 43, 5087-5096. [CrossRef]

21. Buonanno, M.; Welch, D.; Shuryak, I.; Brenner, D.J. Far-UVC light (222 nm) efficiently and safely inactivates airborne human coronaviruses. Sci. Rep. 2020, 10, 1-8. [CrossRef]

22. Torres, A.E.; Lyons, A.B.; Narla, S.; Kohli, I.; Kohli, I.; Parks-Miller, A.; Ozog, D.; Hamzavi, I.H.; Lim, H.W. Ultraviolet-C and other methods of decontamination of filtering facepiece N-95 respirators during the COVID-19 pandemic. Photochem. Photobiol. Sci. 2020, 19, 746-751. [CrossRef]

23. Biasin, M.; Bianco, A.; Pareschi, G.; Cavalleri, A.; Cavatorta, C.; Fenizia, C.; Galli, P.; Lessio, L.; Lualdi, M.; Tombetti, E.; et al. UV-C irradiation is highly effective in inactivating SARS-CoV-2 replication. Sci. Rep. 2021, 11, 1-7. [CrossRef]

24. Cabaj, A.; Sommer, R.; Pribil, W.; Haider, T. The spectral UV sensitivity of microorganisms used in biodosimetry. Water Supply 2002, 2, 175-181. [CrossRef]

25. Mamane-Gravetz, H.; Linden, K.G.; Cabaj, A.; Sommer, R. Spectral sensitivity of Bacillus subtilis spores and MS2 coliphage for validation testing of ultraviolet reactors for water disinfection. Environ. Sci. Technol. 2005, 39, 7845-7852. [CrossRef]

26. Hylander, L.D.; Goodsite, M.E. Environmental costs of mercury pollution. Sci. Total Environ. 2006, 368, 352-370. [CrossRef]

27. Asif Khan, M. AlGaN multiple quantum well based deep UV LEDs and their applications. Phys. Status Solidi 2006, 203, 1764-1770. [CrossRef]

28. Shatalov, M.; Jain, R.; Saxena, T.; Dobrinsky, A.; Shur, M. Development of Deep UV LEDs and Current Problems in Material and Device Technology. Semicond. Semimet. 2017, 96, 45-83. [CrossRef]

29. Trivellin, N.; Monti, D.; De Santi, C.; Buffolo, M.; Meneghesso, G.; Zanoni, E.; Meneghini, M. Current induced degradation study on state of the art DUV LEDs. Microelectron. Reliab. 2018, 88-90, 868-872. [CrossRef]

30. Amano, H.; Collazo, R.; De Santi, C.; Einfeldt, S.; Funato, M.; Glaab, J.; Hagedorn, S.; Hirano, A.; Hirayama, H.; Ishii, R.; et al. The 2020 UV emitter roadmap. J. Phys. D Appl. Phys. 2020, 53, 503001. [CrossRef]

31. Endruweit, A.; Johnson, M.S.; Long, A.C. Curing of composite components by ultraviolet radiation: A review. Polym. Compos. 2006, 27, 119-128. [CrossRef]

32. Hockberger, P.E. A History of Ultraviolet Photobiology for Humans, Animals and Microorganisms. Photochem. Photobiol. 2007, 76, 561-579. [CrossRef]

33. Dreyer, C.; Mildner, F. Application of LEDs for UV-Curing; Springer Series in Materials Science; Springer International Publishing: Cham, Switzerland, 2016; pp. 415-434.

34. Schirripa Spagnolo, G.; Cozzella, L.; Simonetti, C. Banknote security using a biometric-like technique: A hylemetric approach. Meas. Sci. Technol. 2010, 21, 055501. [CrossRef]

35. Won, W.-S.; Tran, L.G.; Park, W.-T.; Kim, K.-K.; Shin, C.S.; Kim, N.; Kim, Y.-J.; Yoon, Y.-J. UV-LEDs for the Disinfection and Bio-Sensing Applications. Int. J. Precis. Eng. Manuf. 2018, 19, 1901-1915. [CrossRef] 
36. Kemény, L.; Varga, E.; Novak, Z. Advances in phototherapy for psoriasis and atopic dermatitis. Expert Rev. Clin. Immunol. 2019, 15, 1205-1214. [CrossRef] [PubMed]

37. Vieyra-Garcia, P.A.; Wolf, P. A deep dive into UV-based phototherapy: Mechanisms of action and emerging molecular targets in inflammation and cancer. Pharmacol. Ther. 2021, 222, 107784. [CrossRef] [PubMed]

38. Glickman, G.; Byrne, B.; Pineda, C.; Hauck, W.W.; Brainard, G.C. Light Therapy for Seasonal Affective Disorder with Blue Narrow-Band Light-Emitting Diodes (LEDs). Biol. Psychiatry 2006, 59, 502-507. [CrossRef] [PubMed]

39. Paradiso, R.; Proietti, S. Light-Quality Manipulation to Control Plant Growth and Photomorphogenesis in Greenhouse Horticulture: The State of the Art and the Opportunities of Modern LED Systems. J. Plant Growth Regul. 2021. [CrossRef]

40. Schreiner, M.; Martínez-Abaigar, J.; Glaab, J.; Jansen, M. UV-B Induced Secondary Plant Metabolites. Opt. Photonik 2014, 9, 34-37. [CrossRef]

41. Shur, M.S.; Gaska, R. Deep-Ultraviolet Light-Emitting Diodes. IEEE Trans. Electron. Devices 2010, 57, 12-25. [CrossRef]

42. Žukauskas, A.; Kurilčik, N.; Vitta, P.; Juršènas, S.; Bakienè, E.; Gaska, R. Optimization of a UV light-Emitting Diode Based FluorescencePhase Sensor; Carrano, J.C., Zukauskas, A., Eds.; Optically Based Biological and Chemical Detection for Defence III: Stockholm, Sweden, 2006; p. 63980Y.

43. Mori, M.; Hamamoto, A.; Takahashi, A.; Nakano, M.; Wakikawa, N.; Tachibana, S.; Ikehara, T.; Nakaya, Y.; Akutagawa, M.; Kinouchi, Y. Development of a new water sterilization device with a 365 nm UV-LED. Med. Biol. Eng. Comput. 2007, 45, 1237-1241. [CrossRef]

44. Würtele, M.A.; Kolbe, T.; Lipsz, M.; Külberg, A.; Weyers, M.; Kneissl, M.; Jekel, M. Application of GaN-based ultraviolet-C light emitting diodes-UV LEDs-for water disinfection. Water Res. 2011, 45, 1481-1489. [CrossRef]

45. Kowalski, W.J.; Walsh, T.J.; Petraitis, V. COVID-19 Coronavirus Ultraviolet Susceptibility 2020 COVID-19 Coronavirus Ultraviolet Susceptibility; PurpleSun Inc.: Long Island City, NY, USA, 2020; pp. 1-4. [CrossRef]

46. Inagaki, H.; Saito, A.; Sugiyama, H.; Okabayashi, T.; Fujimoto, S. Rapid inactivation of SARS-CoV-2 with deep-UV LED irradiation. Emerg. Microbes Infect. 2020, 9, 1744-1747. [CrossRef]

47. Ran, Z.; Yao, M.; Li, S. Comparison of UVA-LED and UVC-LED for Water Disinfection: Inactivation of Escherichia coli; Sustainable Development of Water and Environment. ICSDWE 2020; Jeon, H.Y., Ed.; Springer: Cham, Switzerland, 2020 ; pp. 39-49.

48. Chatterley, C.; Linden, K.G. UV-LED Irradiation Technology for Point-of-Use Water Disinfection. Proc. Water Environ. Fed. 2009, 2009, 222-225. [CrossRef]

49. Pramanik, P.; Das, S.; Adhikary, A.; Chaudhuri, C.R.; Bhattacharyya, A. Design and implementation of water purification system based on deep ultraviolet light emitting diodes and a multi-pass geometry reactor. J. Water Health 2020, 18, 306-313. [CrossRef]

50. Anyaogu, K.C.; Ermoshkin, A.A.; Neckers, D.C.; Mejiritski, A.; Grinevich, O.; Fedorov, A.V. Performance of the light emitting diodes versus conventional light sources in the UV light cured formulations. J. Appl. Polym. Sci. 2007, 105, 803-808. [CrossRef]

51. Hao, G.-D.; Tamari, N.; Obata, T.; Kinoshita, T.; Inoue, S. Electrical determination of current injection and internal quantum efficiencies in AlGaN-based deep-ultraviolet light-emitting diodes. Opt. Express 2017, 25, A639. [CrossRef] [PubMed]

52. Zhao, H.; Liu, G.; Zhang, J.; Arif, R.A.; Tansu, N. Analysis of internal quantum efficiency and current injection efficiency in III-nitride light-emitting diodes. IEEE/OSA J. Disp. Technol. 2013, 9, 212-225. [CrossRef]

53. Cho, J.; Schubert, E.F.; Kim, J.K. Efficiency droop in light-emitting diodes: Challenges and countermeasures. Laser Photon. Rev. 2013, 7, 408-421. [CrossRef]

54. Piva, F.; De Santi, C.; Deki, M.; Kushimoto, M.; Amano, H.; Tomozawa, H.; Shibata, N.; Meneghesso, G.; Zanoni, E.; Meneghini, M. Modeling the degradation mechanisms of AlGaN-based UV-C LEDs: From injection efficiency to mid-gap state generation. Photon. Res. 2020, 8, 1786. [CrossRef]

55. Yun, J.; Shim, J.I.; Hirayama, H. Analysis of efficiency droop in 280-nm AlGaN multiple-quantum-well light-emitting diodes based on carrier rate equation. Appl. Phys. Express 2015, 8, 022104. [CrossRef]

56. De Santi, C.; Meneghini, M.; Tibaldi, A.; Vallone, M.; Goano, M.; Bertazzi, F.; Verzellesi, G.; Meneghesso, G.; Zanoni, E. Physical Mechanisms Limiting the Performance and the Reliability of GaN-Based LEDs; Elsevier Ltd.: Amsterdam, The Netherlands, 2017; ISBN 9780081019436.

57. Piva, F.; De Santi, C.; Deki, M.; Kushimoto, M.; Amano, H.; Tomozawa, H.; Shibata, N.; Meneghesso, G.; Zanoni, E.; Meneghini, M. Stability and degradation of AlGaN-based UV-B LEDs: Role of doping and semiconductor defects. Microelectron. Reliab. 2019, 100-101, 113418. [CrossRef]

58. Haller, C.; Carlin, J.F.; Jacopin, G.; Martin, D.; Butté, R.; Grandjean, N. Burying non-radiative defects in InGaN underlayer to increase InGaN/GaN quantum well efficiency. Appl. Phys. Lett. 2017, 111, 262101. [CrossRef]

59. Nagai, S.; Yamada, K.; Hirano, A.; Ippommatsu, M.; Ito, M.; Morishima, N.; Aosaki, K.; Honda, Y.; Amano, H.; Akasaki, I. Development of highly durable deep-ultraviolet AlGaN-based LED multichip array with hemispherical encapsulated structures using a selected resin through a detailed feasibility study. Jpn. J. Appl. Phys. 2016, 55, 082101. [CrossRef]

60. Trivellin, N.; Monti, D.; Piva, F.; Buffolo, M.; De Santi, C.; Zanoni, E.; Meneghesso, G.; Meneghini, M. Degradation processes of $280 \mathrm{~nm}$ high power DUV LEDs: Impact on parasitic luminescence. Jpn. J. Appl. Phys. 2019, 58, SCCC19. [CrossRef]

61. Yoshikawa, A.; Hasegawa, R.; Morishita, T.; Nagase, K.; Yamada, S.; Grandusky, J.; Mann, J.; Miller, A.; Schowalter, L.J. Improve efficiency and long lifetime UVC LEDs with wavelengths between 230 and $237 \mathrm{~nm}$. Appl. Phys. Express 2020, $13,022001$. [CrossRef] 
62. Monti, D.; De Santi, C.; Da Ruos, S.; Piva, F.; Glaab, J.; Rass, J.; Einfeldt, S.; Mehnke, F.; Enslin, J.; Wernicke, T.; et al. HighCurrent Stress of UV-B (In)AlGaN-Based LEDs: Defect-Generation and Diffusion Processes. IEEE Trans. Electron. Devices 2019, 66, 3387-3392. [CrossRef]

63. Glaab, J.; Haefke, J.; Ruschel, J.; Brendel, M.; Rass, J.; Kolbe, T.; Knauer, A.; Weyers, M.; Einfeldt, S.; Guttmann, M.; et al. Degradation effects of the active region in UV-C light-emitting diodes. J. Appl. Phys. 2018, 123. [CrossRef]

64. Ruschel, J.; Glaab, J.; Beidoun, B.; Ploch, N.L.; Rass, J.; Kolbe, T.; Knauer, A.; Weyers, M.; Einfeldt, S.; Kneissl, M. Current-induced degradation and lifetime prediction of $310 \mathrm{~nm}$ ultraviolet light-emitting diodes. Photon. Res. 2019, 7, B36. [CrossRef]

65. Glaab, J.; Ruschel, J.; Kolbe, T.; Knauer, A.; Rass, J.; Cho, H.K.; Lobo Ploch, N.; Kreutzmann, S.; Einfeldt, S.; Weyers, M.; et al. Degradation of (In)AlGaN-Based UVB LEDs and Migration of Hydrogen. IEEE Photon. Technol. Lett. 2019, 31, 529-532. [CrossRef]

66. Meneghini, M.; Barbisan, D.; Rodighiero, L.; Meneghesso, G.; Zanoni, E. Analysis of the physical processes responsible for the degradation of deep-ultraviolet light emitting diodes. Appl. Phys. Lett. 2010, 97, 14-17. [CrossRef]

67. Heilingloh, C.S.; Aufderhorst, U.W.; Schipper, L.; Dittmer, U.; Witzke, O.; Yang, D.; Zheng, X.; Sutter, K.; Trilling, M.; Alt, M.; et al. Susceptibility of SARS-CoV-2 to UV irradiation. Am. J. Infect. Control 2020, 48, 1273-1275. [CrossRef] [PubMed]

68. Bormann, M.; Alt, M.; Schipper, L.; van de Sand, L.; Otte, M.; Meister, T.L.; Dittmer, U.; Witzke, O.; Steinmann, E.; Krawczyk, A. Disinfection of sars-cov-2 contaminated surfaces of personal items with uvc-led disinfection boxes. Viruses 2021, $13,598$. [CrossRef]

69. Liu, S.; Luo, W.; Li, D.; Yuan, Y.; Tong, W.; Kang, J.; Wang, Y.; Li, D.; Rong, X.; Wang, T.; et al. Sec-Eliminating the SARS-CoV-2 by AlGaN Based High Power Deep Ultraviolet Light Source. Adv. Funct. Mater. 2021, 31, 2008452. [CrossRef]

70. Kitagawa, H.; Nomura, T.; Nazmul, T.; Omori, K.; Shigemoto, N.; Sakaguchi, T.; Ohge, H. Effectiveness of 222-nm ultraviolet light on disinfecting SARS-CoV-2 surface contamination. Am. J. Infect. Control 2021, 49, 299-301. [CrossRef]

71. Sabino, C.P.; Sellera, F.P.; Sales-Medina, D.F.; Machado, R.R.G.; Durigon, E.L.; Freitas-Junior, L.H.; Ribeiro, M.S. UV-C (254 nm) lethal doses for SARS-CoV-2. Photodiagnosis Photodyn. Ther. 2020, 32, 101995. [CrossRef]

72. Minamikawa, T.; Koma, T.; Suzuki, A.; Mizuno, T.; Nagamatsu, K.; Arimochi, H.; Tsuchiya, K.; Matsuoka, K.; Yasui, T.; Yasutomo, K.; et al. Quantitative evaluation of SARS-CoV-2 inactivation using a deep ultraviolet light-emitting diode. Sci. Rep. 2021, 11, 1-9. [CrossRef]

73. Trivellin, N.; Buffolo, M.; Onelia, F.; Pizzolato, A.; Barbato, M.; Orlandi, V.T.; Del Vecchio, C.; Dughiero, F.; Zanoni, E.; Meneghesso, G.; et al. Inactivating SARS-CoV-2 Using $275 \mathrm{~nm}$ UV-C LEDs through a Spherical Irradiation Box: Design, Characterization and Validation. Materials 2021, 14, 2315. [CrossRef] [PubMed]

74. OMS Water, Sanitation, Hygiene and Waste Management for the COVID-19 Virus; World Health Organization: Geneva, Switzerland, 2020; pp. 1-9.

75. $\mathrm{Hu}, \mathrm{Y}$; Cheng, H. Mercury risk from fluorescent lamps in China: Current status and future perspective. Environ. Int. 2012, 44, 141-150. [CrossRef]

76. Education, I.M.; Hampshire, N.; Island, R.; Lamps, F. IMERC Fact Sheet Mercury Use in Lighting Types of Mercury Lamps; NEWMOA, Northeast Waste Management Officials' Association: Boston, MA, USA, 2001; pp. 1-14.

77. Beyer, R.M.; Manica, A.; Mora, C. Shifts in global bat diversity suggest a possible role of climate change in the emergence of SARS-CoV-1 and SARS-CoV-2. Sci. Total Environ. 2021, 767, 145413. [CrossRef] [PubMed]

78. Shangguan, Z.; Wang, M.Y.; Sun, W. What caused the outbreak of COVID-19 in China: From the perspective of crisis management. Int. J. Environ. Res. Public Health 2020, 17, 3279. [CrossRef] [PubMed]

79. Mazzoleni, S.; Turchetti, G.; Ambrosino, N. The COVID-19 outbreak: From "black swan" to global challenges and opportunities. Pulmonology 2020, 26, 117-118. [CrossRef] [PubMed]

80. Dreyer, C.; Mildner, F. III-Nitride Ultraviolet Emitters; Kneissl, M., Rass, J., Eds.; Springer Series in Materials Science; Springer International Publishing: Cham, Switzerland, 2016; Volume 227, ISBN 978-3-319-24098-5.

81. Khan, M.H.; Yadav, H. Sanitization During and After COVID-19 Pandemic: A Short Review. Trans. Indian Natl. Acad. Eng. 2020, 5, 617-627. [CrossRef] 